\title{
The Use of Creative Problem Solving Instructional Model in Improving Students' Ability to Write Complex Procedure Text
}

\author{
Sanggup Barus \\ Department of Indonesian Language and Literature \\ Universitas Negeri Medan \\ Medan, Indonesia \\ Corresponding author: \\ sanggupbarus101154@gmail.com
}

\author{
Abdul Hasan Saragih \\ Study Program Education Technology \\ Post Graduate Universitas Negeri Medan \\ Medan, Indonesia
}

\author{
Sahat Siagian \\ Study Program Education Technology \\ Post Graduate Universitas Negeri Medan \\ Medan, Indonesia
}

\begin{abstract}
This study aims to know whether the use of creative problem solving instructional model can improve the students' ability to write complex procedure text. The approach used in this research was quantitative descriptive approach. The method used was quasi experimental method. The instrument used to capture data was a test instrument of the ability to write complex procedure text. Data analysis technique used was comparative technique by using pre-test and post-test one group design. The results showed three points. First, the ability to write complex procedures text before using creative problem solving instructional model is classified into low category. Second, the ability to write complex procedure text after using creative problem solving instructional model belongs to good category. Third, the use of creative problem solving instructional model can improve the ability to write complex procedure text.
\end{abstract}

Keywords - creative problem solving instructional model; writing ability; complex procedure text

\section{INTRODUCTION}

Writing ability is one of the important aspects of language ability. In this era of information technology, as an educated nation, of course, people feel less satisfied if they can only obtain information or ideas sourced from other nations by using their reading ability. They also want to convey information or ideas useful to other nations or to mankind in writing. In this case, the ability to write becomes very important.

One of the types of writing ability is the ability to write complex procedure text. This type of ability is very important possessed by students because in writing a variety of academic writings that usually become a task in college, such as writing proposal, thesis, scientific articles, and so on, this type of skill is really necessary. In these writings, there are also micro genres, one of which is the procedure.
Mahsun (2014: 30) states that complex procedure text is one of a kind of text that includes the factual genre of procedural subgenre [1]. In this case, complex procedure text is a text that describes the way or steps in a complete, clear and detailed way of doing things. The writing aims to provide an explanation of how or steps to do something clearly.

Kosasih (2014: 68) states that complex procedure text is divided into objective formulation (preliminary), discussion steps, and closing [2]. In this case, the objective contains an introduction that relates to the working instructions section of the discussion. In addition, in this section, it may be also stated the objective of writing other clues. The steps of the discussion contain instructions on the work of something arranged regularly. In general, this section is organized in chronological order. However, there are also sequences made based on the most important to the less important. Based on the contents, complex procedure text can be distinguished into three kinds, namely the text that contains the means of using tools, objects, or other similar devices, texts that contain the ways of doing an activity, and the text containing the habits or ways of how to get used to something useful in life. Then, the closing contains the necessary sentences that are not in the form of a conclusion, but as a marker that the text is finished.

According to Kosasih (2014:71), that in terms of language, there are several rules that apply to complex procedure text namely as follows. Because it is a clue, complex procedure text uses many command phrases, which consequently many use the verb imperative, for example, make, arrange, seek out, must, don't, and so on. In the complex procedure text, temporal conjunction or conjunctives are widely used to denote the timelines of activities, such as and, later, after that and subsequently. The words are used as a consequence of the steps of using something that is chronological. As a result, such texts demand the presence of conjunctions that are 
chronologically meaningful as well. In similar texts a lot of adverb of time is used for timing words, like a few minutes later, half an hour. The words are widely used in recipes. Sometimes in the text, it is used words that state the sequence of activity steps, such as first, second, third and so on. In complex procedure text, adverbs of manner are widely used, for example quickly, gently, slowly and so on. In similar texts, technical words are widely used according to the theme.

For example, in traffic instructions, many use words such as driver's license, fines, criminal offenses, evidence of violation, trial, judge's decision. In the recipe instructions, there is also a detailed description of the name of the object used, including the number, sequence, or shape [3].

Based on these matters, it can be stated that in an effort to improve the quality of human resources, it is necessary that writing instructional in educational institutions can provide optimal writing ability in the students themselves. However, the reality shows that the ability to write complex procedure text of the students of Department of Language and Literature, Universitas Negeri Medan is still low. From the interviews conducted with the lecturers of writing, it is known that the mastery of how to write complex procedure text can be judged relatively good, but the ability of students to write in text types is still low. This problem is almost the same condition as in high school. Alam (2017:23) states that the average value of producing complex procedure text obtained by grade $\mathrm{X}$, the students of State High School 3 Ciamis is 60 [4]. This average score has not shown satisfactory learning outcomes. Of course, this is due to the lack of efforts of lecturers or teachers to involve students in learning actively, especially their mental.

The author offers an effort to learn to write complex procedure text namely the use of creative problem solving instructional model. This instructional model was developed by Alex Osborn and Sidney Parness in the 1960s. Chant, Maes, and Ross in Maharani, Wahyu and Sugianto (2015: 207) suggest that creative problem solving is one of the instructional models that can be used to enhance the ability to think creatively [5]. Shoimin (2014:56) states that the creative problem solving instructional model is an instructional model that focuses on teaching and problem-solving ability followed by strengthening of ability. When faced with a question, students can do problem-solving ability to select and develop responses. It is not just by memorizing without thinking, problem-solving ability expand the thinking process [6].

Creative problem solving (hereinafter abbreviated as CPS) has the objective of enabling students to apply problemsolving steps in the CPS, being able to discover possible problem-solving strategies, being able to evaluate and select those possibilities and their relation to existing criteria, able to choose an optimal solution choice, able to develop a plan in implementing problem solving strategies and able to articulate how CPS can be used in various fields or situations. In this case, Huda (2014:298) states that in the CPS, the teacher is assigned with directing creative problem-solving efforts. He also served to provide learning materials or discussion topics that can stimulate students to think creatively in solving problems [7].

Shoimin (2013:57) states that by using the CPS instructional model, the instructional steps taken by the students are as follows. First, students clarify the problems as posed by the teacher by the way of listening to the

explanations given so that the student can understand the solution as expected. Second, students freely express opinions on various problem-solving strategies. Third, students evaluate and select opinions or strategies that are suitable for solving problems through discussion activities undertaken by each group. Fourth, in this implementation step, students determine which strategies can be taken to solve the problem, then apply it until they find the solution to the problem [8]. In this fourth step, students apply it in the activity of writing complex procedure text.

The problem to be answered in this research is as follows. How is the ability of the students to write complex procedure text before using CPS learning model? How is the ability of the students to write complex procedure text after using CPS learning model? Does the use of CPS learning models improve the ability of the students to write complex procedure texts? In accordance with the problem, this study aims to know the ability of the student to write complex procedure text before using the CPS learning model, to know the ability of the students to write complex procedure text after using the CPS learning model, and to know whether the use of the CPS learning model can improve the ability of the student to write complex procedure text.

It has been previously stated that the writing process of complex procedure text after writing the objectives, the author describes problem solving, namely the ways of steps to do something (by using tools, how to do something or how to be accustomed to doing something). It shows that in order to write complex procedure text, it is necessary to have knowledge regarding what to discuss, creative thinking activity, and the mastery of the rules of language required. The fulfillment of the rules can be done by the use of CPS model. With discussion group in using CPS instructional model, the student are freely to express their opinion regarding various ways in solving problem, to evaluate and select the most appropriate opinion or strategy in solving problem or the way to do something, and discuss the rules to follow in the writing of complex procedure text. Therefore, it can be expected that the use of the CPS instructional model influences the possibility of writing complex procedure text.

Based on that framework, hypotheses can be formulated as follows. There is a positive influence of the use of the CPS instructional model on the ability of the students to write complex procedure text. If the hypothesis is tested, then it can be stated that the use of the CPS instructional model can improve the ability of the students to write complex procedure text. 


\section{METHOD}

This study was conducted on the students of Language and Literature Program Study, Faculty of Languages and Literature Universitas Negeri Medan semester 1 year 2017. Subjects of this study amounted to 26 people.

The approach used in this research was quantitative descriptive approach. The method used was quasi experimental method. The design of this research was one group pre-test and post-test design that can be seen in the table below.

This research has two variables, namely CPS instructional model and writing ability of the student to write complex procedure text. The operational definition is that the CPS instructional model is a form of learning that consists of steps to clarify the problem, express the opinion of various ways or steps to work things out, evaluate and select the appropriate opinion, and implement the opinion taken and apply it in writing complex procedure text. The ability to write complex procedure text is a score that students acquire after studying or practicing writing complex procedure text using the CPS instructional model.

Data collection is done by the test technique that is the ability to write complex procedure text. In this case, students are assigned to write a complex procedure text by using linguistic structures and rules that apply in the text of complex procedures. The topic is how to cope with flooding in the village. Aspects assessed in complex procedures text are content, content organization, use of language, and mechanistic matters.

TABLE 1. Research Design

\begin{tabular}{|c|c|c|c|}
\hline Class & Pre-test & Treatment & Post-test \\
\hline Experiment & $\mathrm{O} 1$ & $\mathrm{X}$ & $\mathrm{O} 2$ \\
\hline
\end{tabular}

Remarks :

O1 : Test of writing ability complex procedure text before using CPS instructional model.

$\mathrm{X}$ : Treatment by using CPS instructional model.

$\mathrm{O} 2$ : Test of writing ability complex procedure text after using CPS instructional model.

TABLE 2. Grid of Instrument for Writing Ability of the Students to Write Complex Procedure Text

\begin{tabular}{|l|c|c|c|c|c|c|}
\hline \multicolumn{1}{|c|}{$\begin{array}{c}\text { Assessment } \\
\text { Criteria }\end{array}$} & Excellent & Good & Sufficient & Less & Failed & $\begin{array}{c}\text { Percen } \\
\text { tage }\end{array}$ \\
\hline $\begin{array}{l}\text { Content: The } \\
\text { appropriateness of } \\
\text { content with topic } \\
\text { and the } \\
\text { completeness of } \\
\text { description for } \\
\text { every part of the } \\
\text { text. }\end{array}$ & $25-21$ & $20-16$ & $15-11$ & $10-6$ & $5-0$ & $25 \%$ \\
\hline $\begin{array}{l}\text { Content } \\
\text { Organization : } \\
\text { Good orderly } \\
\text { content } \\
\text { arrangement and }\end{array}$ & $25-21$ & $20-16$ & $15-11$ & $10-6$ & $5-0$ & $25 \%$ \\
\hline
\end{tabular}

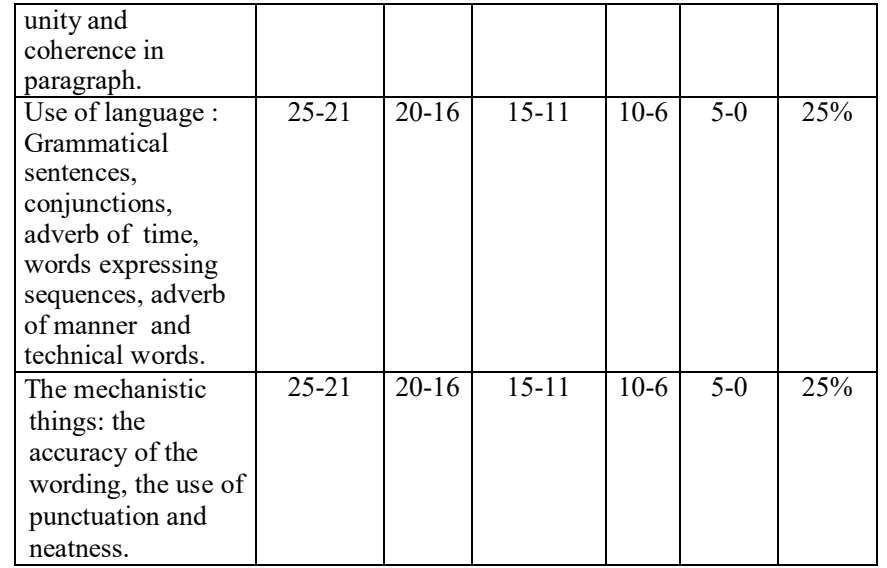

The categories of writing ability of complex procedure text used in this study are the categories declared by Sudijono (2008:35), which is excellent (80-100), good (66-79), sufficient (56-65), less (46-55) and failed (0-45). This category is used to know the description or level of student ability in writing complex procedure text before using CPS instructional model and after using CPS instructional learning model.

To find out whether the use of the CPS instructional model in writing complex procedure text can improve students' writing skills, it is used comparational techniques with t-test (Arikunto, 2013-349), that is experimental analysis technique using pre-test and post-test one group design [10].

\section{RESULTS AND DISCUSSION}

The number of scores obtained by all students from the pre-test (before using the CPS learning model) is 1338. The average score is 51,46 . Using the capability category made by Sudijono, the average score is categorized into less categories. However, since students have already studied the writing of complex procedure text at the previous level of education, the average pre-test score can still be categorized low.

The number of scores obtained by all students from the post-test, after learning using the CPS instructional model is 1789. The average score is 68,8 . The average score of the student in this post-test is in the range 66-79. Therefore, the average score can be categorized good.

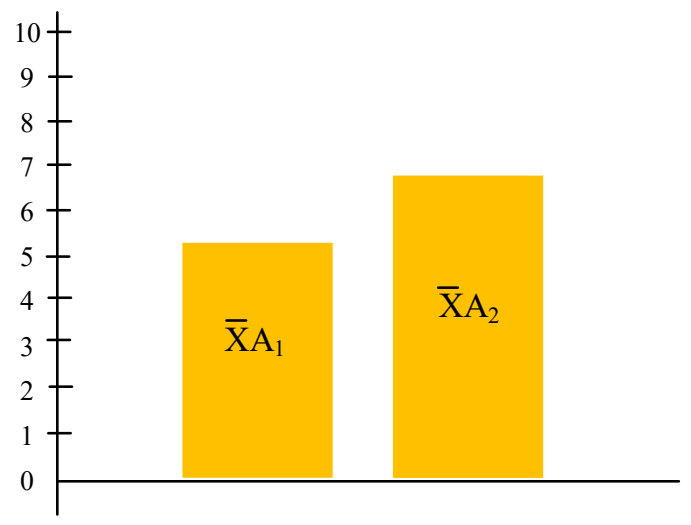

Fig. of Diagram Difference in Mean Score Writing Ability Complex Procedure Text from Pre-Test and Post-Test 


\section{Remarks :}

$\overline{\mathrm{X}} \mathrm{A}_{1}$ : The average score of writing ability of complex procedure text from pre-test (before using the CPS learning model).

$\overline{\mathrm{X}} \mathrm{A}_{2}$ : The average score of writing ability of complex procedure text from post-test (after using the CPS learning model).

To know the difference between the average score, it can be seen clearly in the figure above.

To know whether the difference between the two average scores was significant or not, a hypothesis test was tested with a t-test as stated in the previous discussion. In this case, the test data analysis requirements performed is data normality test and data homogeneity test. The normality test of group A1 (sourced from pre-test) and A2 (sourced from post-test) was done by Lilliefors test. Homogeneity test of both data groups was done by $\mathrm{F}$ test.

Results of normality test data A1 and A2 can be seen in the table below.

Table 3 shows that from the two group data (A1 and A2), it is obtained Lo $<$ Ltable. It is therefore, it can be stated that the data of writing ability of complex procedure text of the students before using CPS instructional model (sourced from pre-test) and the data of writing capability of complex procedure text of the students after using CPS instructional model (sourced from post-test) is normally distributed.

Results of homogenity test of the two data group can be seen in table 4 below.

Table 4 shows that from the two data group (A1 and A2), it is obtained $F_{\text {calculated }}<F_{\text {table }}(1,69<1,95)$. It is therefore, it can be stated that the varians data of writing capability of complex procedure text for group $\mathrm{A}_{1}$ (before using CPS instructional model) and the varians data of writing capability of complex procedure text for group $\mathrm{A}_{2}$ (after using CPS instructional model) is homogen.

TABLE 3. Results of Normality Group Data Test $A_{1}$ and $A_{2}$

\begin{tabular}{|c|c|c|c|c|}
\hline $\begin{array}{c}\text { Data } \\
\text { Group }\end{array}$ & $\mathbf{N}$ & \multirow{2}{*}{ Lo } & Ltabel & \multirow{2}{*}{ Simpulan } \\
\cline { 4 - 4 } & & & $\boldsymbol{\alpha}=\mathbf{0 , 0 5}$ & \\
\hline $\mathrm{A}_{1}$ & 26 & 0,1400 & 0,171 & Normal \\
\hline $\mathrm{A}_{2}$ & 26 & 0,1198 & 0,171 & Normal \\
\hline
\end{tabular}

TABLE 4. Results of Homogenity Test Group Data $A_{1}$ and $A_{2}$

\begin{tabular}{|c|c|c|c|c|c|c|}
\hline $\begin{array}{c}\text { Data } \\
\text { Group }\end{array}$ & $\mathbf{n}$ & Dk & $\mathbf{s i}^{2}$ & $F_{\text {calculated }}$ & $\begin{array}{c}\mathbf{F}_{\text {table }} \\
\alpha=\mathbf{\alpha}=\mathbf{0 5} \\
\end{array}$ & Conclusion \\
\hline $\mathrm{A}_{1}$ & 26 & 25 & 43,1942 & \multirow{2}{*}{1,69} & \multirow{2}{*}{1,95} & \multirow{2}{*}{ Homogen } \\
\hline $\mathrm{A}_{2}$ & 26 & 25 & 72,9152 & & & \\
\hline
\end{tabular}

With the fulfillment of the requirements of this analysis, the hypothesis of this study can be tested. The result of hypothesis test of this research shows that at the significance level $\alpha=0,05$ and $n=26, \mathrm{t}_{\text {calculated }}>\mathrm{t}_{\text {table }}(10.98>1.71)$.

Thus, the hypothesis of this study is acceptable. That is, there is a positive and significant influence of the use of CPS instructional model on the ability to write complex procedure text. Therefore, it can be stated that the use of the CPS instructional model can improve the ability to write complex procedure text.

In connection with the results of the study, there are several things that need to be discussed. First, the average score of the ability to write complex procedure text on each aspect of ability can be seen in the table below.

Table 5 shows that the average score of the students on the content aspect before the use of the CPS instructional model was 13.04 and after the use of the CPS instructional model was 19.23 . That means that there is an increase of $6.19 \%$. The average scores of the students on organizational aspects of content before the use of the CPS instructional model was $12.84 \%$ and after the use of the CPS instructional model was 18.70. That means that there is an increase of $2.35 \%$. Then, the average student score on the mechanistic aspects before the use of the CPS instructional model was 11.50 and after the use of the CPS instructional model was 14.38. That means that there is an increase of $2.88 \%$.

The increase in the student's average score is prominent in content and content organization aspects. It can be interpreted that this is because students are helped in learning using CPS instructional model. With the freedom of giving opinions and discussion activities in the instructional activities, students have the opportunity to think creatively to generate opinions that are relevant in solving the problem. In addition, by using the CPS instructional model, students have the opportunity to gather various opinions in their group to find ways or steps to overcome the flood in the village.

TABLE 5. Average Score of the Students' Ability to Write Complex Procedure Text on Every Aspect of Ability

\begin{tabular}{|l|c|c|c|}
\hline \multicolumn{1}{|c|}{$\begin{array}{c}\text { Capability } \\
\text { Aspect }\end{array}$} & $\begin{array}{c}\text { Average } \\
\text { Score Before } \\
\text { Using CPS } \\
\text { Instructional } \\
\text { Model }\end{array}$ & $\begin{array}{c}\text { Average Score } \\
\text { After Using } \\
\text { CPS } \\
\text { Instructional } \\
\text { Model }\end{array}$ & $\begin{array}{c}\text { The } \\
\text { Improvement } \\
(\%)\end{array}$ \\
\hline Content & 13,04 & 19,23 & $6,19 \%$ \\
\hline $\begin{array}{l}\text { Organization } \\
\text { content }\end{array}$ & 12,84 & 18,70 & $5,86 \%$ \\
\hline Use of Language & 14,11 & 16,46 & $2,35 \%$ \\
\hline $\begin{array}{l}\text { Mechanistic } \\
\text { things }\end{array}$ & 11,50 & 14,38 & $2,88 \%$ \\
\hline
\end{tabular}

The increase in scores or students' average scores on aspects of language usage and mechanistic matters is relatively low. It can be interpreted that this is due to the influence of the relatively low use of the CPS instructional model on the students' ability to write complex procedure text in terms of language use and mechanistic matters. Therefore, specifically to improve students' ability on the aspects of language use and mechanistic matters, the lecturer should observe carefully in terms of what the underprivileged students are, both on the aspects of language use and mechanistic matters. Thus, lecturers can plan in terms of what needs to be emphasized on both aspects of the assessment to be implemented in learning using the CPS instructional model.

Secondly, on the basis of that interpretation, it can be stated that to produce good complex procedure text, the writer (student) must 
have sufficient knowledge of the subject to be discussed, ideas as the result of creative thinking, and knowledge of the use of language and things the mechanistic required. Competence is crucial to the quality of the text of complex procedures.

Third, the results of this study can be used as one of the considerations in the planning of learning programs to write complex procedure text, especially in the planning of instructional method. Because it turns out that learning to write complex procedures text can work well by using the CPS instructional model.

In addition, in practice, the use of the CPS instructional model can realize the principles of efficiency and effectiveness in complex procedure text writing lessons. This is similar to Tuckman's opinion in Gomes (2007:34) which states that creative problem solving in carefully regulated group situations is not only effective, but also economical in terms of the use of time [11]. The use of the CPS instructional model can train students to think creatively to generate ideas or opinions creatively in their efforts to express ways or steps to work. Because it can activate mentally, learning to write complex procedure text with the use of this instructional model can motivate students in learning. In practice, lecturers only act as facilitators and mentors. Lecturers only give a brief explanation of the topic to be discussed and provide brief guidance on learning procedures with the CPS instructional model.

Thus, it is the results of this study and discussion. However, learning to write complex procedure text using this CPS instructional model requires careful preparation. Lecturers should be able to make their lesson plans and manage their implementation well and fun.

\section{CONCLUSION}

Based on the results and discussion in this study, it can be concluded as follows. The ability to write complex procedure text of the student before using CPS instructional model is categorized less. The ability to write complex procedure text after using the CPS instructional model is categorized well. The use of the CPS instructional model can improve the ability to write complex procedure text.

\section{ACKNOWLEDGEMENT}

This research was conducted on the support from Chairman of Study Program Indonesian Language and Literature, Faculty of Language and Arts Universitas Negeri Medan.

\section{REFERENCES}

[1] Mahsun, Teks dalam Pembelajaran Bahasa Indonesia Kurikulum 2013. Jakarta: RajaGrafindo Persada, 2014

[2] E. Kosasih, Jenis-jenis Teks dalam Mata Pelajaran Bahasa Indonesia $S M A / M A / S M K$. Bandung: Yrama Widya, 2014

[3] E. Kosasih, Jenis-jenis Teks dalam Mata Pelajaran Bahasa Indonesia $S M A / M A / S M K$. Bandung: Yrama Widya, 2014

[4] Hendri Wira Nur Alam, 'Peningkatan Kemampuan Memproduksi Teks Prosedur Kompleks dengan Menggunakan Metode Demonstrasi' in Jurnal Diksatrasia, Volume 1 Nomor 1 April 2017

[5] H.R. Maharani, S.B. Waluya, dan Sugianto, 'Humanistic Mathematics Learning with Creative Problem Solving Assisted Interactive Compact Disk to Improve Creative Thinking Ability' in International Journal of Education and Research, Vol.3 No. 1 January 2015

[6] Aris Shoimin, 68 Model Pembelajaran Inovatif dalam Kurikulum 2013. Yogyakarta : Ar-Ruzz Media, 2014

[7] Miftahul Huda, Model-model Pengajaran dan Pembelajaran : Isu-isu Metodis dan Paradigmatis. Yogyakarta: Pustaka Pelajar, 2014

[8] Aris Shoimin, 68 Model Pembelajaran Inovatif dalam Kurikulum 2013. Yogyakarta: Ar-Ruzz Media, 2014

[9] Anas Sudijono, Pengantar Evaluasi Pendidikan. Jakarta: RajaGrafindo Persada, 2008

[10] Suharsimi Arikunto, Prosedur Penelitian Suatu Pendekatan Praktik. Jakarta: Rineka Cipta, 2013

[11] Jose G. Gomes, 'What Do We Know About Creativity?' in The Journal of Effective Teaching, Volume 7/Issue 1/February 2007, Online at http://www.edu/cte/et/, Diakses pada 10 April 2018 